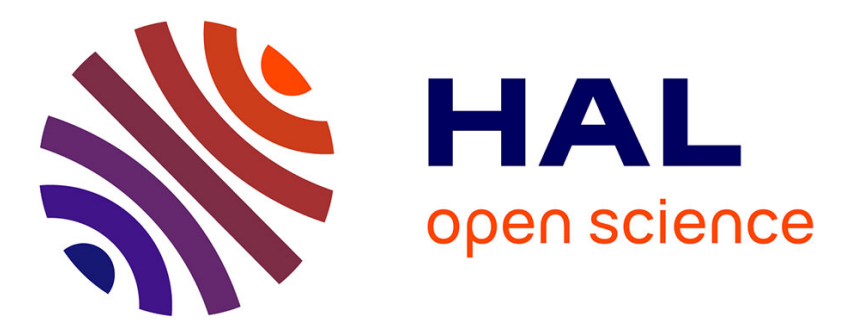

\title{
Production situations as drivers of crop health: evidence and implications
}

\author{
Serge Savary, Neil Mcroberts, Paul D. Esker, Laetitia Willocquet, Paul S. Teng
}

\section{To cite this version:}

Serge Savary, Neil Mcroberts, Paul D. Esker, Laetitia Willocquet, Paul S. Teng. Production situations as drivers of crop health: evidence and implications. Plant Pathology, 2017, 66 (6), pp.867-876. $10.1111 /$ ppa.12659 . hal-01608624

\section{HAL Id: hal-01608624 \\ https://hal.science/hal-01608624}

Submitted on 26 May 2020

HAL is a multi-disciplinary open access archive for the deposit and dissemination of scientific research documents, whether they are published or not. The documents may come from teaching and research institutions in France or abroad, or from public or private research centers.
L'archive ouverte pluridisciplinaire HAL, est destinée au dépôt et à la diffusion de documents scientifiques de niveau recherche, publiés ou non, émanant des établissements d'enseignement et de recherche français ou étrangers, des laboratoires publics ou privés. 
Received Date : 27-Jun-2016

Revised Date : 04-Nov-2016

Accepted Date : 18-Nov-2016

Article type : Letter to the Editor

\title{
Production situations as drivers of crop health: evidence and implications
}

\author{
Serge Savary, Neil McRoberts, Paul D. Esker, Laetitia Willocquet, and Paul S. Teng
}

First and fourth author: INRA, Centre de Toulouse, UMR AGIR, BP 52627, 31326 Catanet-Tolosan; Université Toulouse, INPT, UMR AGIR, F-31029 Toulouse, France; Second author: Plant Pathology Department, University of California, Davis CA, 95616, USA; Third author: Centro para Investigaciones en Granos y Semillas, Universidad de Costa Rica, San José, Costa Rica; and fifth author: Natural Science and Science Education, National Institute of Education, Nanyang Technological University, 637616 Singapore.

Corresponding author: S. Savary; E-mail address: Serge.Savary@toulouse.inra.fr

We witness unprecedented changes in Earth's natural and man-made ecosystems. These changes are generated by a number of drivers - human population growth, global trade, climate change, and technology shifts - which are often linked in their evolutions, and compounded in their impacts (Vitousek et al., 1986; Rosen, 2000). Importantly, these drivers of change are not linear in their dynamics, evolve at different speeds, and act upon the diversity of the biosphere through different mechanisms, resulting in heterogeneous impacts (Cassman et al., 2005; Garrett et al., 2011). Agriculture may be seen both as a recipient of these effects as well as a cause of changes in the biosphere. As with any of the interactions at play in an ecosystem, plant disease displays responses to these changes.

This article has been accepted for publication and undergone full peer review but has not been through the copyediting, typesetting, pagination and proofreading process, which may lead to differences between this version and the Version of Record. Please cite this article as doi: 10.1111/ppa.12659

This article is protected by copyright.All rights reserved. 
An important issue for plant pathologists is to identify the different responses of plant pathosystems to these changes, to quantify them, to link them with proximate and ultimate causes, and to foresee future evolutions. These steps are necessary to design durable disease management strategies, as part of any strategy for future global food security.

We propose in this letter a possible framework for such an analysis. Central to this framework are the concepts of "production situation" and "crop health". For both concepts, we attempt to provide conceptual definitions, which we convert into operational definitions (Zadoks 1972), that is to say, definitions which enable formal assessment. We then proceed to address the linkages between production situation and crop health, and their implications.

\section{A community ecology approach to crop health: injury profiles}

Crops are exposed to a range of harmful organisms, much in the same way as human beings are exposed to different pathogens. In the plant sciences, these organisms are collectively referred to as 'pests' (including pathogens, arthropods, or weeds). Depending on a number of factors, this multiple exposure may lead to the establishment and reproduction of several pests on any given host crop. As a consequence, crops are often affected by more than one pest (Padwick 1956; McRoberts et al., 2003; Kranz 2005; Savary et al., 2006). These multiple-pest populations may interact in terms of their dynamics (e.g., Johnson et al., 1987; Al-Naimi et al., 2005; Kranz 2005; Garrett et al., 2011), as well as with respect to their yield-reducing effects on crops (Padwick 1956; Johnson et al., 1986; Kranz 2005; Savary et al., 2006).

Multiple-pest syndromes in crops may be considered from an ecological point of view as an example of ecological communities, for which concepts such as fundamental niche and realized niche (Al-Naimi et al., 2005), or niche occupancy and resource use (McRoberts et al., 2003) can be applied. Crop harmful organisms can also be grouped according to functional properties such as their patterns of dynamics, and addressed in terms of epidemiological patterns (Kranz 1978). Another functional property of crop harmful organisms is their physiological effect on crops (damage mechanism), that is to say, their effects on the plant physiology (Rabbinge and Rijsdijk 1981; Boote et al., 1983). Crop

This article is protected by copyright.All rights reserved. 
harmful agents may be grouped as guilds representing the physiological disorders they cause to host plants (Savary et al., 2006).

We have previously proposed (Savary et al 2006) that the term 'injury profile' be used to describe this collective effect of multiple factors on crop health. Crop health in itself is a fuzzy term (Döring et al., 2012), which encompasses plant pathogens and animal pests, but also abiotic environmental factors, in their negative effects on plant physiology, growth, or reproduction. As an operational definition for crop health, we propose to restrict ourselves to plant pathogens and animal pests, as follows: Crop health can be assessed as the set of multiple injuries that may occur in the course of a crop cycle or season, simultaneously or successively. Crop health can thus be represented by a vector of injury levels, which we call Injury Profile (IP). Elements of the injury profile (Table 1) may be measured with different metrics, such as maximum severity (e.g., shoot diseases), maximum incidence (e.g., systemic or fruit diseases), or the area under disease severity (of, e.g., foliar diseases). Choice of the metric for injury levels is based on the damage mechanisms associated with each disease or animal pest (Savary et al., 2006).

\section{A systems approach to production situations: crop profiles}

The context - ecological, technical, social, economical - where disease occurs is essential to understand and manage crop health. We use the concept of production situation to express this context. Following Breman \& de Wit (1983), we call 'production situation' the matrix where a crop is established, grows, is managed and harvested, and is consumed or traded. A production situation has been defined as the bio-physical and socio-economic environment where agricultural production takes place (Penning de Vries \& Van Laar 1982; Breman \& De Wit 1983; Rabbinge \& De Wit 1989). A production situation may thus be decomposed into components which account for the physical, biological, economic, social, and technological environment of agriculture.

Multidimensional characterization of production situations typically involves qualitative and quantitative systems attributes, such as cumulated rainfall, plant genotype, field size, crop establishment method, inputs, or crop rotation. As an operational definition of a production situation, 
we propose the Crop Profile (CP), i.e., a vector of production situation attributes. A typical CP includes elements of the cropping practices (Table 2). Cropping practices actually reflect farmers' adaptations to their economic, environmental, and social contexts. Cropping practices also correspond to the mobilization of resources (human labour, capital, land, know-how), which may be, at least in part, substitutable (Table 2; Van Ittersum \& Rabbinge, 1997).

\section{Crop health depends on production situations: evidence}

Empirical evidence of a strong relationship between crop health, represented by injury profiles (IP,

Table 1), and production situations, represented by crop profiles, (CP, Table 2) has been found in several systems across a range of environments: wheat in Europe (Daamen et al., 1989, Willocquet $e t$ al., 2008); groundnut in West Africa (Savary et al., 1988); lowland rice of tropical Asia (Savary et al., 2006; Reddy et al., 2011); and coffee in Central America (Avelino et al., 2006; Alline et al., 2016). Sampled fields in these different systems were grouped according to CPs and IPs, leading to the detection of strong associations between these two meta-variables. This research led to four main findings:

- Despite the very large theoretical number of combinations of CPs by IPs, each study on these different agrosystems found that only a limited number of possible [CP x IP] combinations occurred. Thus, even if each crop stand is unique in its characteristics, the observed variability can be restricted to a limited set of [CP x IP] combinations, which may become distinct targets for crop health management.

- The same crop profile (i.e., production situation) and a related injury profile (i.e., crop health) can be found at very different locations. As a result, [production situation $\mathrm{x}$ crop health], and so, [CP $\mathrm{x}$ IP] associations, are not site-specific. It is also possible to see two different crop profiles and their associated injury profiles in the same area (Savary et al., 2006). This finding has very important implications when defining recommendation domains (Teng and Savary 1992) for crop health management: two neighbouring fields may profoundly differ with respect to their production situations and crop health status.

This article is protected by copyright. All rights reserved. 
- Analysis of [CP x IP] data within a Bayesian framework (Mila and Carriquiry 2004) shows that production situations can be considered as risk factors for crop health (Savary et al., 2011a).

- Associations between whole CPs and entire IPs, i.e., [CP x IP] linkages were found to be stronger than linkages occurring at a lower level of hierarchy, i.e., between individual CP and individual IP components (Savary et al., 2011a). For instance, a given CP component (e.g., relative crop establishment date, or nitrogen fertilizer input) has a weaker linkage with the levels of a given IP component, e.g., a particular disease injury, than do entire CPs, that is, production situations as wholes.

The above findings imply that a profound shift in paradigm is needed, to delink natural geographical influence on crop health (which is intuitive) from the stronger influence of production situations (which are imposed by human interventions caused by agriculture). They also indicate the value of a holistic approach, which involves the entire $\mathrm{CP}$, to derive strategies for crop health management.

\section{Production situations determine attainable yields}

Linking the concepts of production situation and crop health to yield and yield loss requires the consideration of the yield level of a given crop that is not injured by pests. This level has been defined as the attainable yield (Zadoks \& Schein, 1979; Rabbinge \& De Wit, 1989; Van Ittersum \& Rabbinge, 1997). The attainable yield of a crop is determined by the combination of factors affecting a crop during its lifespan - yield-defining factors (which determine the potential yield: temperature, radiation, genotype of the crop), and yield-limiting factors (which restrict yield increase beyond an attainable level: nutrients and water supply; Zadoks \& Schein, 1979; Van Ittersum \& Rabbinge, 1997). A given production situation thus incorporates both yield-defining and yield-limiting factors, and therefore determines the attainable yield of this crop. Yield loss is defined in turn as the difference between the attainable (Ya) and the actual yield (Y) of a crop (Zadoks \& Schein, 1979; Chiarappa, 1980; Teng, 1987; Esker et al., 2012). The attainable yield therefore is the reference yield used to measure yield losses to injuries: Ya - Y.

This article is protected by copyright.All rights reserved. 


\section{A systems framework for production situations, crop health, and yield losses}

A framework is needed to analyse the relationships between production situations (represented by their crop profile, CP), crop health (represented by injury profiles, IP), and yield performances, represented by the attainable yield and the losses with respect to this attainable yield. Figure 1 provides a simplified, diagrammatic representation of these relations. In this framework, a number of components of the crop profile of a given production situation are highlighted in terms of inputs: labour $(\mathrm{L})$, water $(\mathrm{W})$, fertiliser $(\mathrm{F})$, pesticides $(\mathrm{P})$, varieties $(\mathrm{V})$, and technologies $(\mathrm{T})$. The latter component pertains to a number of important elements of agricultural production, such as land preparation and levelling, crop establishment and geometry, or seed purity and health. A crop profile leads to a given level of attainable yield, which is a characteristic of a production situation. A crop profile is also associated with an injury profile, which characterizes crop health in the considered production situation. Lastly, the dynamic interactions between harmful organisms that are part of the injury profile and the yield-determining physiological processes of a growing crop lead to yield losses.

\section{Application of the framework to three agrosystems}

The following section illustrates the use of the framework of Figure 1 in three distinct agrosystems.

\subsection{The groundnut agrosystem in West Africa}

Groundnut is cultivated in many countries of West Africa on small (less than 1 ha) fields, at often low crop density (T), with no chemical (fertilizers and pesticide) inputs (F), and limited manual labour (L;

Fig. 2A). Except in Senegal, this is often a low input crop, which is part of small-scale farming rotations, and also a component of household gardens. Groundnut has largely escaped decades of technical and extension efforts that targeted large-field (1-5 ha) crops such as cotton, maize, or sorghum. Three diseases of groundnut are particularly widespread in West Africa (Savary et al., 1988): early leafspot (ELS, caused by Cercospora arachidicola), late leafspot (LLS, Phaeoisariopsis personata), and rust (GR, Puccinia arachidis). ELS frequently occurs in poor stands where water shortage is frequent, while LLS predominates in denser, more humid stands. GR is a newcomer in the

This article is protected by copyright.All rights reserved. 
groundnut multiple pathosystem (Savary et al., 1988), and prevails in well-established and well-tended stands.

The three diseases differ epidemiologically. ELS and LLS are predominantly spread by rain, whereas GR spores are strongly dispersed by wind (Savary et al., 1988; 1990). The diseases also differ in damage mechanisms: ELS is caused by a strong necrotroph, a light stealer that reduces LAI through its foliage lesions, and even more so through rapid leaf senescence and defoliation. LLS does not cause as rapid a defoliation as ELS, but strongly reduces light interception through very rapid lesion multiplication. By contrast, GR only colonizes a limited fraction of LAI even at the highest possible severities. But it is a very powerful assimilate sapper that converts plant carbohydrates in fungal biomass and spores (Savary et al., 1990), which translates in increasing yield losses with both rust severity and attainable yield (Savary et al., 1988; Esker et al., 2012).

The productivity of this traditional agrosystem is low, with average actual yields in the range of 3 to $600 \mathrm{~kg} \cdot \mathrm{ha}^{-1}$. Attempts to increase crop productivity (Fig. 2B) have included three steps (1) higher seeding density (T), (2) some limited mineral fertilization (F), and (3) more frequent weeding (L). Field experimental work (Savary et al., 1988; Esker et al., 2012) has shown that (1) while this path of

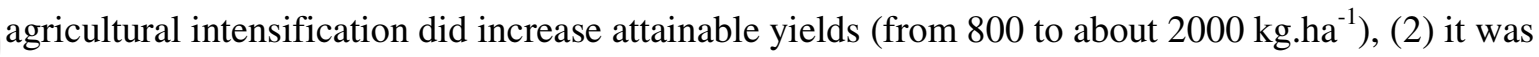
accompanied by an increase in GR severity and a decrease of ELS, (3) leading to strongly increased yield losses (from 300 to $800 \mathrm{~kg} \cdot \mathrm{ha}^{-1}$ ).

In the above example, the intensification process leads to increased attainable yields, as well as a change in injury profile, from a profile dominated by necrotroph pathogens to a profile dominated by rust. This new injury profile leads to increased yield losses, not only because of the increased level of rust, but also because the yield-reducing effect of rust increases with the attainable yield. The gain in actual yield expected from an improved production situation is therefore negated by the change in injury profile. In this system, a threshold for attainable yield is evidenced (Savary et al., 1988), above which disease (rust) control is needed to increase the actual yield. This leads to recommending the improvement of rust management through varietal resistance where production situation is more intensive, in order to enable intensification to translate into higher actual yields.

This article is protected by copyright. All rights reserved. 


\subsection{The wheat agrosystem in France and hardy winter wheat varieties}

Winter wheat is a key crop in North-Western Europe, especially in France. The wheat agrosystem in this part of Europe has experienced a steady productivity increase since the 1960s as a result of regular increase in fertilizer use (F) and pesticides use (herbicides, insecticides, fungicides; P), along with steady breeding efforts (V) to maximize potential yields (Fig. 3A) in an ever-improved technological environment, including knowledge and machines (e.g., Ewert et al., 2015).

The European wheat agrosystem involves several diseases, such as leaf rust (Puccinia triticina), stripe rust (P. striiformis), septoria tritici blotch (Zymoseptoria graminis), and fusarium head blight (caused by a complex of species, including Fusarium graminearum, F. avenaceum, and F. culmorum; Nielsen et al., 2011). These diseases differ in many ways in their epidemiological characteristics (Daamen $e t$ al., 1989; Hardwick et al., 2001; Savary et al., 2016). Septoria tritici blotch is caused by a heminecrotroph, genetically variable (Chen \& McDonald, 1996) pathogen with a strong ability to disperse over short-distance through rain-splash (Shaw \& Royle, 1989). By contrast, the leaf and stripe rust pathogens are long-distance, wind-dispersed with strong evolutionary potential (McDonald \& Linde, 2002). FHB is an increasingly important disease during warm summers when flowering stage coincides with rainy periods (Parry et al, 1995).

These diseases also differ with respect to the injuries they cause (Willocquet et al., 2008). Septoria tritici blotch is a powerful light stealer through the multiplication of lesions it causes on the foliage, which enhances leaf senescence. Leaf and stripe rust also contribute to reduced light interception, but are also assimilate sappers through their spore production. While fusarium head blight reduces yield accumulation, it is responsible for the accumulation of toxins in the grain.

While fungicide use had become a main means to control wheat diseases in Western Europe (Daamen et al., 1989; Hardwick et al., 2001; Savary et al., 2016; Fig. 3A), efforts were undertaken (Fig. 3B) to reduce the dependence of this agrosystem towards fertilisers (especially nitrogen, F) and pesticides (P). The introduction of hardy winter wheat varieties (Doussinault, 1998; Brancourt-Hulmel et al., 2003) in the system, with strong competitive ability and quantitative resistances to diseases (leaf rust, septoria tritici blotch, stripe rust, eyespot; Loyce et al., 2008), enables a decreased sowing density and a reduction of fungicide inputs. Hardy winter wheat varieties actually constitute the starting point 
for different system performances (Fig. 3B), leading to reduced (nitrogen) fertilizer use, limited fungicide applications, and good grain quality. In this extensified system, the reduced attainable yields and the moderately increased disease levels (Savary et al., 2016) are rendered acceptable because of the sustained actual yields and lower operating costs (Loyce et al., 2012).

This second example entails change generated through breeding innovation. In this case, an extensification (reduction of systems inputs) process is at play, leading to a reduction in attainable yield, a lower level of control over diseases, but stabilized (actual) yield and economic performances.

\subsection{The lowland rice agrosystem of tropical Asia}

The lowland rice agrosystem of tropical Asia represents a critical system for global food security (Evenson \& Gollin, 2003), which encompasses a very large diversity of production situations (Greenland, 1997). Several studies (Savary et al., 2006) have reported the characterization of rice crop profiles, of injury profiles, and their linkages. One main conclusion is that, beyond the wide diversity of their components, only a few crop profiles, and a few injury profiles, are sufficient to account for a large fraction of situations observed in farmers' fields. In many ways, the results suggest that, as resources available to agriculture become scarcer, agricultural change progresses at a faster pace. All the components of the crop profile are reflecting ongoing changes (Fig. 4A): labour availability (L, which translates in, e.g., crop establishment methods and weeding), water supply (W, and its implication in land preparation and irrigation), fertiliser inputs $(\mathrm{F})$, pesticide use $(\mathrm{P})$, diversity and shifts in varieties (V), and a wide range of agricultural technologies.

A wide range of harmful organisms are involved in rice injury profiles (Table 1) including Fungi, Viruses, and Bacteria, with very diverse epidemiological characteristics, and which are associated with a whole array of injury mechanisms, which we cannot discuss in detail here.

In the recent years, massive changes in crop profiles have taken place, as (1) fertilizer inputs have strongly increased, (2) pesticides, and especially fungicides, have been used more frequently, and (3) hybrid material has been deployed over large areas. These changes have been evidenced from analyses on over 1,000 farmers' fields (Savary, 2014) surveyed between 1987 and 2011 in tropical Asia. Changes in crop profile are associated with shifts in injury profiles, such as the emergence of false 
smut (Villosiclava virens) and widespread epidemics of plant-hopper transmitted virus diseases including ragged stunt. Despite the large increase in (chemical) inputs, no significant yield increase has been detected (Savary, 2014), suggesting an actual decline in total factor productivity (Pingali, 2012) of this critical agroecosystem. The complex interplay of (partly substitutable) components of the crop profile is shown in Fig. 4B, leading to highly variable attainable yields, and strong shifts in injury profile composition. As a result, yield losses (Ya-Y) are chronically variable.

\section{The production situation nexus}

This note started with a statement on the changes ecosystems are undergoing, and their implications on plant disease in agrosystems. The framework of Figure 1, and its applications in Figures 2-4, allow a visualisation of recent or ongoing changes. We propose another framework to address the future of crop health in agrosystems.

Four global factors drive changes in production situations worldwide: population growth, technology shifts, global trade, and climate change (Rosen, 2000). Population growth is a driver for changes of many kinds, which are aimed at fulfilling global food, feed, and fibre needs (Vitousek et al., 1986), and is the main cause of agricultural intensification worldwide (Matson et al., 1997; Cassman et al., 2005; Stevenson et al., 2013). Technology shifts bring in their wake profound changes in both production situations as well as agrosystems performances. Two examples include changes in tillage practices (e.g., no or reduced tillage replacing moldboard plowing in wheat cultivation; McMullen et al., 2012) or in crop establishment (e.g. direct seeding replacing transplanting in rice cultivation; Savary et al., 2005). Technology shifts have often been linked to agricultural intensification, can have very strong implications on ecosystems resources (e.g., water, soils, or human labour), and may trigger shifts in crop health (e.g., increase in fusarium head blight of small cereals [McMullen et al., 2012], but decrease of rice sheath blight [Savary et al., 2005]). Global trade, on the other hand, is a strong determinant of disease spread across continents (e.g., Bebber et al., 2014).

This article is protected by copyright.All rights reserved. 
We refer to these drivers of change collectively as "global change", to include climate change. As global change induces major changes in production situations, changes in production situations lead in turn to shifts in crop health. Empirical evidence actually suggests that the indirect effect of global change on crop health via production situations is faster than the direct effects of climate change on individual diseases and crop health (Savary et al., 2011b).

The new framework of Fig. 5A emphasizes on the process (represented by a rate-valve symbol; Forrester, 1961) of yield reduction by plant harmful organisms. This process can be expected to occur in any future contexts, irrespective of changes in production situations and crop health. According to

Fig. 5A, future production situations will command the level of attainable yields (Ya), and will determine crop health. A feed-back loop indicates that crop health may in turn influence production situations. Since a production situation also encapsulates the economic and social context of agriculture, it becomes the nexus where crop production and disease development meet in the technological, social, and economical matrix of agriculture. From a crop health perspective, the production situation therefore becomes the scale of efficient management.

\section{From disease to crop health management}

Table 3 is an elaboration of Rosen (2000), from ecology to plant pathology, which proposes an avenue for research in crop health management. Crop health management addresses the management of injury profiles, instead of individual diseases; being focused on a production situation, it emphasizes its long term sustainability in a systems approach where the both social and biological sciences are involved.

Table 3 also indicates desirable change of time- (from one to several seasons), space- (from one field to populations of fields or crop stands) and decision-scales (from tactical to strategic).

Another avenue concerns the multiple dimensions of crop losses, which is addressed in Figure 5B (Savary et al., 2006; Cheatham et al., 2011). Each unit of yield which is lost to pests corresponds to commensurate losses of resources invested in the crop: land, water, energy, nutrients, expertise, cultural, and economic (Table 2). Yield losses to pests therefore translate into a multidimensional (social, economic, ecological, and cultural) attrition of agricultural systems. The multidimensionality of crop losses implies a double penalty for farmers, communities, and ecosystems (Savary et al., 2006; 
2011b), and links plant pathology to the management of ecosystem services (Cheatham et al., 2009), a novel direction for future research.

Crop health, as public health, is a collective good (INRA, 2015). From this perspective, the challenge will be to find ways to preserve and enhance crop health globally, a collective goal towards which policies may play a major role. Applications and implications of risk factor analysis to crop health echoes the massive, large-scale studies that are conducted on public health, where the importance of considering diseases and their collective impacts is emphasized (medical doctors refer to "disease burden", to be borne by individuals - and society), rather than analyses on individual diseases (Lim et al., 2013).

\section{Literature cited}

Alline C, Savary S, Avelino J, 2016. Delicate balance between pest and disease injuries, yield performance, and other ecosystem services in the complex coffee-based systems of Costa Rica. Agriculture Ecosystem and Environment 222, 1-12.

Al-Naimi FA, Garrett KA, Bockus WW, 2005. Competition, facilitation, and niche differentiation in two foliar pathogens. Oecologia 143, 449-457.

Avelino J, Zelaya H, Merlo A, Pineda A, Ordoñez M, Savary S., 2006. The intensity of a coffee rust epidemic is dependent on production situations. Ecological Modelling 197, 431-447.

Ayres PG, 1981. Effects of Disease on the Physiology of the Growing Plant. Cambridge: Cambridge University Press.

Bebber DP, Holmes T, Gurr SJ, 2014. The global spread of crop pests and pathogens. Global Ecology and Biogeography 23, 1398-1407.

Boote KJ, Jones JW, Mishoe, JW, Berger RD, 1983. Coupling pests to crop growth simulators to predict yield reductions. Phytopathology 73, 1581-1587.

Brancourt-Hulmel M, Doussinault G, Lecomte S, Bérard P, Le Buanec B, Trottet M, 2003. Genetic improvement f agronomic traits of winter wheat cultivars released in France from 1946 to 1992. Crop Science 43, 37-45.

This article is protected by copyright. All rights reserved. 
Breman H, De Wit C T, 1983. Rangeland productivity and exploitation in the Sahel. Science 221, $1341-1347$.

Cassman KG, Wood S, Choo PS, Cooper HD, Devendra C, Dixon J, Gaskell J et al., 2005. Cultivated systems. In: Ecosystem and Human Well-Being, Millennium Ecosystem Assessment, Current State and Trends, Vol. 1, Washington, D.C.: Island Press, Pages 741-789.

Cheatham MR, Rouse MN, Esker PD, Ignacio S, Pradel W, Raymundo R, Sparks AH, Forbes GA, Gordon TR, Garrett KA, 2009. Beyond yield: Plant disease in the context of ecosystem services. Phytopathology 99, 1228-1236.

Chen RS, McDonald BA, 1996. Sexual reproduction plays a major role in the genetic structure of populations of the fungus Mycosphaerella graminicola. Genetics 142, 1119-1127.

Chiarappa, L. 1980. Crop Loss Assessment Methods. Supplement №3 FAO / Comm. Agric. Bureaux: Farnham, England.

Daamen RA, Wijnands FG, Van der Vliet G, 1989. Epidemics of diseases and pests of winter wheat at different levels of agrochemical input. A study on the possibilities for designing an integrated cropping system. Journal of Phytopathology 125, 305-319.

Döring TF, Pautasso M, Finckh MR, Wolfe MS, 2012. Concepts of plant health-reviewing and challenging the foundations of plant protection. Plant Pathology 61, 1-15.

Doussinault G, 1998. La sélection pour des variétés adaptées à une agriculture durable. Dossiers Environnement 16, 39-44.

Esker PD, Savary S, McRoberts N, 2012. Crop loss analysis and global food supply: focusing now on required harvests. $C A B$ Reviews 7 (n ${ }^{\circ}$ 52), 1-14.

Evenson DE, Gollin D, 2003. Assessing the Impact of the Green Revolution, 1960 to 2000. Science 300, $758-762$.

Ewert F, Rounsevell MDA, Reginster I, Metzger MJ, Leemans R, 2005. Future scenarios of European agricultural land use. I. Estimating changes in crop productivity. Agriculture, Ecosystems and Environment 107, 101-116.

Forrester JW, 1961. Industrial Dynamics. Cambridge (Mass.): M.I.T. Press.

This article is protected by copyright.All rights reserved. 
Garrett KA, Forbes GA, Savary S, Skelsey P, Sparks AH, van Bruggen AHC, Valdivia C, Willocquet L, Djurle A, Duveiller E, Eckersten H, Pande S, Vera Cruz C, Yuen J, 2011. Complexity in climate change impacts: A framework for analysis of effects mediated by plant diseases. Plant Pathology 60, 15-30.

Greenland DJ, 1997. The Sustainability of Rice Farming. Wallingford, U.K. and Manila, Philippines: CABI and IRRI.

Hardwick NV, Jones DR, Slough JE, 2001. Factors affecting diseases of winter wheat in England and Wales, 1989-98. Plant Pathology 50, 453-462.

INRA, 2015. Gérer la santé des plantes comme un bien commun. Meta-Programme SMaCH (Sustainable Management of Corp Health - INRA), https://inra-dram-front-resourcescdn.brainsonic.com/ressources/afile/270686-9811d-resource-note-bien-commun-smach-2014coleno.html

Johnson KB, Radcliffe EB, Teng PS, 1986. Effects of interacting populations of Alternaria solani, Verticillium dahliae, and the potato leafhopper (Empoasca fabae) on potato yield. Phytopathology 76, 1046-1052.

Johnson KB, Teng PS, Radcliffe EB, 1987. Analysis of potato foliage losses caused by interacting infestations of early blight, Verticillium wilt, and potato leafhopper; and the relationship to yield. Journal of Plant Diseases and Protection 94, 22-33.

Kranz J, 1978. Comparative anatomy of epidemics. In: Horsfall JG, Cowling EB, eds. Plant Disease. An Advanced Treatise, Vol. IV. New York: Academic Press, 33-62.

Kranz J, 2005. Interactions in pest complexes and their effects on yield. Journal of Plant Diseases and Protection 112, 366-385.

Lim SS, Vos T, Flaxman AD, Danaei G, Shibuya K, Adair-Rohani H, ... and Davis A, 2013. A comparative risk assessment of burden of disease and injury attributable to 67 risk factors and risk factor clusters in 21 regions, 1990-2010: a systematic analysis for the Global Burden of Disease Study 2010. The Lancet 380, 2224-2260.

Loyce C, Meynard JM, Bouchard C, Rolland B, Lonnet P, Bataillon P, Bernicot MH, Bonnefoy M, Charrier X, Debote B, Demarquet T, Duperrier B, Félix I, Heddadj D, Leblanc O, Leleu M,

This article is protected by copyright. All rights reserved. 
Mangin P, Méausoone M, Doussinault G, 2008. Interaction between cultivar and crop management effects on winter wheat diseases, lodging, and yield. Crop Protection 27, 11311142.

Loyce C, Meynard JM, Bouchard C, Rolland B, Lonnet P, Bataillon P, ... and Doussinault G, 2012. Growing winter wheat cultivars under different management intensities in France: A multicriteria assessment based on economic, energetic and environmental indicators. Field Crops Research 125, 167-178.

Matson PA, Parton WJ, Power AG, Swift MJ, 1997. Agricultural Intensification and ecosystem properties. Science $\mathbf{2 7 7}$, 504-509.

McDonald BA, Linde C, 2002. Pathogen population genetics, evolutionary potential, and durable resistance. Annual Review of Phytopathology 40, 349-379.

McMullen M, Bergstrom G, De Wolf E, Dill-Macky R, Hershman D, Shaner G, Van Sanford D, 2012. A unified effort to fight an enemy of wheat and barley: Fusarium head blight. Plant Disease 96,1712-1728.

McRoberts N, Hughes G, Savary S, 2003. Integrated approaches to understanding and control of diseases and pests in field crops. Australasian Plant Pathology 32, 167-180.

Mila AL, Carriquiry AL, 2004. Bayesian analysis in plant pathology. Phytopathology 94, 1027-1030.

Nielsen LK, Jensen JD, Nielsen GC, Jensen JE, Spliid NH, Thomsen IK, Justesen AF, Collinge DB, Jørgensen LN, 2011. Fusarium head blight of cereals in Denmark: species complex and related mycotoxins. Phytopathology 101,960-969.

Padwick, GW, 1956. Losses Caused by Plant Diseases in the Tropics. Kew: Commonwealth Mycological Institute Phytopathology Paper №1.

Parry DW, Jenkinson P, McLeod L, 1995. Fusarium ear blight (scab) in small grain cereals-a review. Plant Pathology 44, 207-238.

Penning de Vries FWT, Van Laar HH (Eds), 1982. Simulation of Plant Growth and Crop Production. Wageningen: Pudoc.

Pingali PL, 2012. Green revolution: impacts, limits, and the path ahead. Proceedings of the National Academy of Sciences 109, 12302-12308.

This article is protected by copyright.All rights reserved. 
Rabbinge R, Rijsdijk FH, 1981. Disease and crop physiology: a modeler's point of view. In: Ayres PG, ed. Effects of Disease on the Physiology of the Growing Plants, Cambridge, UK: Cambridge University Press, 201-220.

Rabbinge R, Vereyken PH, 1980. The effect of diseases or pests upon the host. Journal of Plant Diseases and Protection 87, 409-22.

Rabbinge R, Sinke C, Mantel WP, 1983. Yield loss due to cereal aphids and powdery mildew in winter wheat. Mededelingen van de Faculteit Landbouwwetenschappen/Rijksuniversiteit Gent 48, 1159-1168.

Rabbinge R, De Wit CT, 1989. Systems, models and simulation. In: R. Rabbinge, S. A. Ward, and R. van Laar, eds. Simulation and Systems Management in Crop Protection. Wageningen: Pudoc ,315.

Rabbinge R, Rossing WAH, Van der Werf W, 1993. Systems approaches in epidemiology and plant disease management. Netherlands Journal of Plant Pathology 99 (Suppl. 3), 161-171.

Reddy CS, Laha GS, Prasad MS, Krishnaveni D, Castilla NP, Nelson A, Savary S, 2011.

Characterizing multiple linkages between individual diseases, crop health syndromes, germplasm deployment, and rice production situations in India. Field Crops Research 120, 241253.

Rosen C (Ed.), 2000. World Resources 2000-2001: People and ecosystems: The fraying web of life. Elsevier.

Rossing WAH, 1991. Simulation of damage in winter wheat caused by the grain aphid Sitobion avenae. 3. Calculation of damage at various attainable yield levels. Netherlands Journal of Plant Pathology 97, 87-103.

Savary S, Bosc JP, Noirot M, Zadoks JC, 1988. Peanut rust in West Africa: a new component in a multiple pathosystem. Plant Disease 72, 1001-1009.

Savary S, De Jong PD, Rabbinge R., Zadoks JC, 1990. Dynamic simulation of groundnut rust, a preliminary model. Agricultural Systems 32, 113-141.

This article is protected by copyright.All rights reserved. 
Savary S, Castilla NP, Elazegui FA, Teng PS, 2005. Multiple effects of two drivers of agricultural change, labour shortage and water scarcity, on rice pest profiles in tropical Asia. Field Crops Research 91, 263-271.

Savary S, Teng PS, Willocquet L, Nutter FW Jr, 2006. Quantification and modeling of crop losses: A review of purposes. Annual Review of Phytopathology 44, 89-112.

Savary S, Mila A, Willocquet L, Esker PD, Carisse O, McRoberts N, 2011a. Risk factors for crop health under global change and agricultural shifts: a framework of analyses using rice in tropical and subtropical Asia as a model. Phytopathology 101, 696-709.

Savary S, Sparks AH, Willocquet L, Duveiller E, Mahuku G, Forbes G, Garrett KA, Hodson D, Padgham J, Pande S, Sharma M, Yuen J, Djurle A, 2011b. International agricultural research tackling the effects of global and climate changes on plant diseases in the developing world. Plant Disease 95, 1204-1216.

Savary S, 2014. Environmental interactions and multiple forcing leading to shifts and variability of crop yield losses. Phytopathology 104, 150.

Savary S, Jouanin C, Félix I, Gourdain E, Piraux F, Willocquet L, 2016. Assessing plant health in a network of experiments on hardy winter wheat varieties in France: multivariate and risk factor analyses. European Journal of Plant Pathology In Press.

Stevenson JR, Villoria N, Byerlee D, Kelley T, Maredia M, 2013. Green Revolution research saved an estimated 18 to 27 million hectares from being brought into agricultural production.

Proceedings of the National Academy of Sciences 110, 8363-8368.

Shaw MW, Royle DJ, 1989. Airborne inoculum as a major source of Septoria tritici (Mycosphaerella graminicola) infections in winter wheat crops in the UK. Plant Pathology 38, 35-43.

Teng PS, 1987. Quantifying the relationship between disease intensity and yield loss. In: Teng PS, ed. Crop Loss Assessment and Pest Management. St Paul MN: APS Press, 105-113,.

Teng PS, Gaunt RE, 1980. Modelling systems of disease and yield loss in cereals. Agricultural Systems 6, 131-154.

Teng PS, Savary S, 1992. Implementing the systems approach in pest management. Agricultural Systems 40, 237-264.

This article is protected by copyright.All rights reserved. 
Van Ittersum, MK., Rabbinge R, 1997. Concepts in production ecology for analysis and quantification of agricultural input-output combinations. Field Crops Research 52, 197-208.

Vitousek PM, Ehrlich PA, Ehrlich A, Matson PA, 1986. Human appropriation of the products of photosynthesis. Bioscience 36, 368-373.

Willocquet L, Elazegui FA, Castilla N, Fernandez L, Fischer KS, Peng S, Teng PS, Srivastava RK, Singh HM, Zhu D, Savary S, 2004. Research priorities for rice disease and pest management in tropical Asia: a simulation analysis of yield losses and management efficiencies.

Phytopathology 94, 672-682.

Willocquet L, Aubertot JN, Lebard S, Robert C, Lannou C, Savary S, 2008. Simulating multiple pest damage in varying winter wheat production situations. Field Crops Research 107, 12-28.

Zadoks JC, 1972. Methodology of epidemiological research. Annual Review of Phytopathology 10, 253-276.

Zadoks JC, 1985. On the conceptual basis of crop loss assessment: the threshold theory. Annual Review of Phytopathology 23, 455-473.

Zadoks JC, Schein RD, 1979. Epidemiology and Plant Disease Management. New York, USA:

Oxford University Press.

Table 1. Components and metrics in four examples of injury profiles in different crops and agrosystems

\begin{tabular}{|l|l|l|}
\hline Crop & Components of an Injury Profile (a) & Main Damage Mechanisms of a Component (b) \\
\hline Rice (c) & Bacterial blight, AUDPC & Leaf senescence accelerator; light stealer \\
\hline & Stem rot, MaxIT & Tissue consumer; Turgor reducer \\
\hline & Sheath blight, MaxIT & Leaf senescence accelerator \\
\hline & Brown spot, AUDPC & Leaf senescence accelerator; Light stealer \\
\hline & Leaf blast, AUDPC & Photosynthetic rate reducer; Light stealer \\
\hline & Neck blast, MaxIP & Tissue consumer \\
\hline & Rice tungro disease, MaxIW & Stand reducer \\
\hline & Plant hoppers, AUCPC & Assimilate sapper \\
\hline & Rice whorl maggot, AUIPC & Light stealer \\
\hline & Leaf folder, AUIPC & Light stealer \\
\hline & Dead hearts (stem borers), MaxIT & Tissue consumer; Turgor reducer \\
\hline & White heads (stem borers), MaxIP & Tissue consumer \\
\hline & $\begin{array}{l}\text { Weed infestation above canopy, } \\
\text { AUWPC }\end{array}$ & Light stealer \\
\hline & $\begin{array}{l}\text { Weed infestation below canopy, } \\
\text { AUWPC }\end{array}$ & Stand reducer; Light stealer \\
\hline
\end{tabular}

This article is protected by copyright. All rights reserved. 


\begin{tabular}{|l|l|l|}
\hline Coffee (d) & Coffee leaf rust, MaxIL & Assimilate sapper; Light stealer \\
\hline & Brown eye spot disease, MaxIL & Light stealer; Leaf senescence accelerator \\
\hline & Leaf miners, MaxIL & Tissue consumer \\
\hline & Phoma leaf blight, MaxIL & Light stealer; Leaf senescence accelerator \\
\hline & Root-lesion nematodes, MaxD & Tissue consumer \\
\hline & Root-knot nematodes, MaxD & Assimilate sapper \\
\hline & Dieback, MaxIW & Tissue consumer; Turgor reducer; Stand reducer \\
\hline & Thread blight, MaxIW & Tissue consumer; Turgor reducer \\
\hline Wheat (e) & Ceratocystis canker, MaxIW & Tissue consumer; Stand reducer \\
\hline & Brown rust severity, MaxS & Assimilate sapper; Light stealer \\
\hline & Yellow rust severity, MaxS & Assimilate sapper; Light stealer \\
\hline & Fusarium head blight incidence, MaxS & Toxins; Tissue consumer \\
\hline & Powdery mildew severity, MaxS & Light stealer; Assimilate sapper \\
\hline & Septoria tritici blotch severity, MaxS & Photosynthetic rate reducer; Leaf senescence \\
& & accelerator \\
\hline Groundnut (f) & Groundnut rust, AUDPC & Assimilate sapper \\
\hline & Late leafspot, AUDPC & Light stealer; Photosynthetic rate reducer \\
\hline & Early leafspot, AUDPC & Light stealer; Leaf senescence accelerator \\
\hline & Aspergillus niger damping-off, MaxIW & Stand reducer \\
\hline & Aspergillus flavus damping-off, MaxIW & Stand reducer; Toxins \\
\hline & Botryodiplodia collar rot, MaxIW & Tissue consumer; Stand reducer \\
\hline & Sclerotium rolfsii stem rot, MaxIW & Turgor reducer; Stand reducer \\
\hline
\end{tabular}

(a) Metrics for injury profile components: AUDPC: area under disease progress curve (four assessments, incidence at the leaf level); MaxIT: maximum incidence (at the tiller level); MaxIP: maximum incidence (at the panicle level); MaxIW: maximum incidence (at the whole plant level); AUCPC: area under number of plant hoppers caught per hill or sampled quadrat (four assessments); AUIPC: area under injury progress curve (injury at the leaf level); AUWPC: area under weed infestation progress curve; MaxIL: maximum incidence (leaf level); MaxD: maximum soil density; MaxS: maximum severity.

(b) Damage mechanisms correspond to main physiological damages associated to injuries: stand reducer, photosynthetic rate reducer, leaf senescence accelerator, light stealer, assimilate sapper, tissue consumer, turgor reducer, toxin accumulation, and deterioration of product appearance (Rabbinge and Vereyken, 1980; Boote et al, 1983; Esker et al., 2012).

(c) Rice in tropical Asia. From Savary et al., 1994; 2000b.

(d) Coffee in Central America. Simplified, from Avelino et al., 2006; Alline et al., 2016.

(e) Wheat in Western Europe, Willocquet et al., 2008; Savary et al., 2016.

(f) Groundnut in West Africa, Savary et al., 1988.

Table 2. Components and metrics in four examples of crop profiles in different crops and agrosystems

\begin{tabular}{|l|l|l|}
\hline Crop & Components of a Crop Profile & Component determinants (a) \\
\hline Rice (b) & Total mineral fertilizer input, kg.ha ${ }^{-1}$ & Energy; Financial \\
\hline & Fallow period duration preceding rice crop, weeks & Land \\
\hline & Weed control practices, manual or not & Labor; Financial \\
\hline & Insecticide use, number of applications & Financial \\
\hline & Herbicide use, number of applications & Financial \\
\hline & Fungicide use in number of applications & Financial \\
\hline & Accumulated drought stress (number of observed occurrences) & Infrastructure; Climate \\
\hline & Accumulated water excess (number of observed occurrences) & Infrastructure; Climate \\
\hline & Crop establishment method (transplanted or direct-seeded) & Labor \\
\hline
\end{tabular}

This article is protected by copyright.All rights reserved. 


\begin{tabular}{|l|l|l|}
\hline & Crop preceding rice in the same field & Multiple \\
\hline & Variety type: traditional, high-yielding, hybrid & Financial; Infrastructure \\
\hline Coffee (c) & Crop density (distances between rows and plants on rows) & Multiple \\
\hline & Shade percentage & Land \\
\hline & Pruning (coffee, shade trees) operations & Labor \\
\hline & Fertilizer operation (basal, topdressing) & Financial \\
\hline & Weeding (chemical and/or mechanical) & Labor; Energy; Financial \\
\hline & Pesticides, fungicides & Financial \\
\hline & Soil chemistry (pH, $\mathrm{K}, \mathrm{Ca}, \mathrm{Mg}, \mathrm{P}, \mathrm{Cu}$, Fe, Mn, Zn) & Soil \\
\hline & Soil texture (sand, clay, loam) & Soil \\
\hline & Soil organic matter & Soil \\
\hline & Rainfall & Climate \\
\hline & Shading characteristics (Legumes, Banana, Fruit trees) & Labor; Land \\
\hline Wheat (d) & Fertilizer inputs, kg.ha ${ }^{-1}$ & Energy; Financial \\
\hline & Fungicide inputs, number of applications & Financial \\
\hline & Crop growth regulators, number of applications & Financial \\
\hline & Seeding rate & Financial \\
\hline & Variety type (hardy or conventional high-yielding) & Technology; Infrastructure \\
\hline Peanut (e) & Ground preparation (mounds, raised beds, ridges, or flat) & Labor; Energy \\
\hline & $\begin{array}{l}\text { Crop association: with maize, millet, sorghum, cassava, tomato, } \\
\text { other annual legume }\end{array}$ & Multiple \\
\hline & Crop density & Multiple \\
\hline & Mineral fertilizer & Financial \\
\hline & Weeding & Labor \\
\hline & & \\
\hline & & \\
\hline
\end{tabular}

(a) A component determinant refers to resources which determine the use of a given crop profile component, and influence the substitutability (Van Ittersum and Rabbinge, 1997) of this crop profile component in a given production situation.

(b) Rice in tropical Asia. From Savary et al., 1994; 2000b. Additional crop profile components pertaining to climatic conditions are not listed.

(c) Coffee in Central America. Simplified, from Avelino et al., 2006; Alline et al., 2016.

(d) Wheat in Western Europe, Willocquet et al., 2008; Savary et al., 2016.

(e) Peanut in West Africa, Savary et al., 1988.

This article is protected by copyright. All rights reserved. 
Table 3. Research approaches: conventional disease management and crop health management ${ }^{a}$

\begin{tabular}{|c|c|c|}
\hline & Conventional Disease Management & Crop Health Management \\
\hline Objective & $\begin{array}{l}\text { - Minimize yield losses to } \\
\text { individual diseases } \\
\text { - Emphasizes net present crop } \\
\text { value } \\
\text { - Focuses on current crop } \\
\text { performances }\end{array}$ & $\begin{array}{l}\text { - Minimize yield loss to injury } \\
\text { - Empofiles } \\
\text { - } \quad \text { long term } \\
\text { - Focuses on systems sustainability }\end{array}$ \\
\hline Scale & $\begin{array}{l}\text { - A field at a given location in a } \\
\text { given year }\end{array}$ & $\begin{array}{l}\text { - A population of fields belonging to } \\
\text { the same production situation }\end{array}$ \\
\hline Role of Science & $\begin{array}{l}\text { - Views disease management as } \\
\text { an applied science }\end{array}$ & $\begin{array}{l}\text { - Views crop health management as } \\
\text { combined biological and social } \\
\text { sciences in a systems approach }\end{array}$ \\
\hline Role of Management & $\begin{array}{l}\text { - Considers one disease at a time } \\
\text { - Focuses on tactical decisions to } \\
\text { manage individual diseases } \\
\text { - Strives to avoid losses to one } \\
\text { disease in one season }\end{array}$ & $\begin{array}{l}\text { - Considers Crop Health as a whole } \\
\text { - Focuses on strategic decisions to } \\
\text { improve crop health } \\
\text { - Strives to minimize losses to } \\
\text { multiple diseases over growing } \\
\text { seasons }\end{array}$ \\
\hline
\end{tabular}

${ }^{\text {a }}$ Adapted from Rosen C (ed.), 2000.

This article is protected by copyright.All rights reserved. 
Figure 1 A systems framework for production situations, crop health, and yield losses

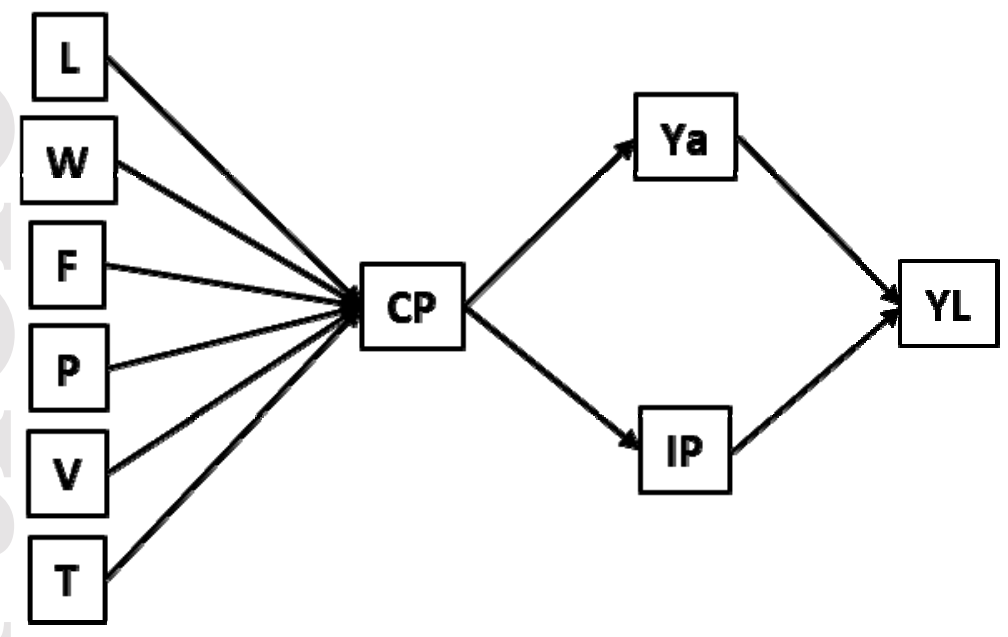

CP: crop profile; IP: injury profile; Ya: attainable yield; YL: yield loss;

L: labour; W: water; F: fertiliser; P: pesticides; V: varieties and germplasm; T: technology level.

Figure 2 Production situations, crop health, and yield losses in the groundnut agrosystem in West Africa
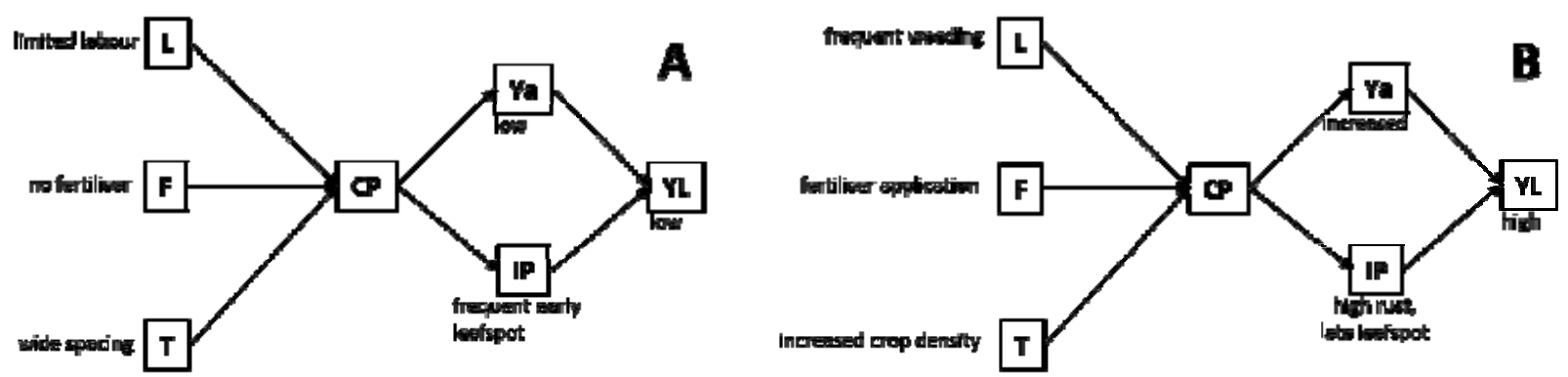

A: conventional system; B: intensified system.

CP: crop profile; IP: injury profile; Ya: attainable yield; YL: yield loss; L: labour; F: fertiliser; T: technology level.

This article is protected by copyright. All rights reserved. 
Figure 3 Production situations, crop health, and yield losses in the wheat agrosystem in Western Europe
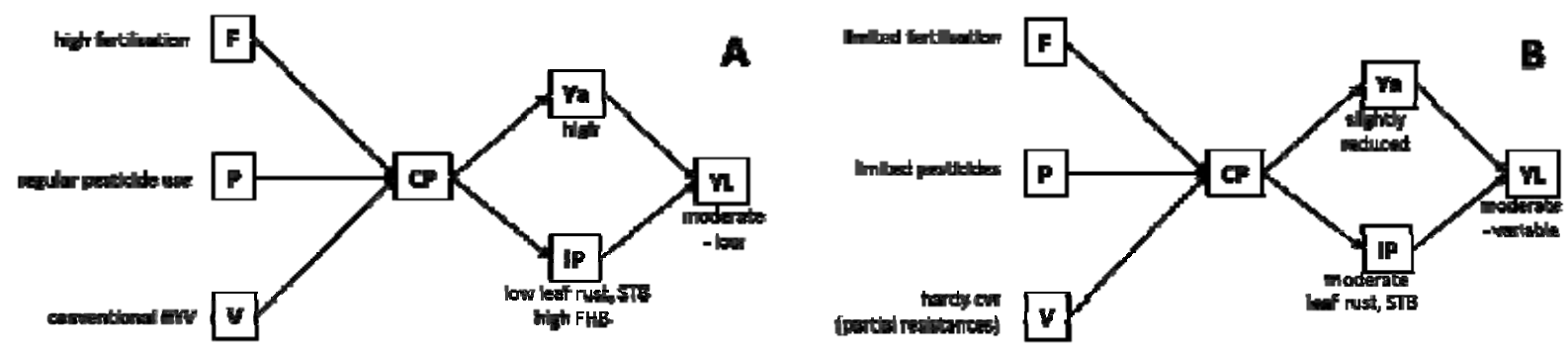

$A$ : conventional intensive system; $B$ : wheat system with hardy varieties.

CP: crop profile; IP: injury profile; Ya: attainable yield; YL: yield loss; F: fertiliser; P: pesticides; V:

varieties and germplasm; HYV: high yielding varieties.

Figure 4 Production situations, crop health, and yield losses in the lowland rice agrosystem in tropical Asia
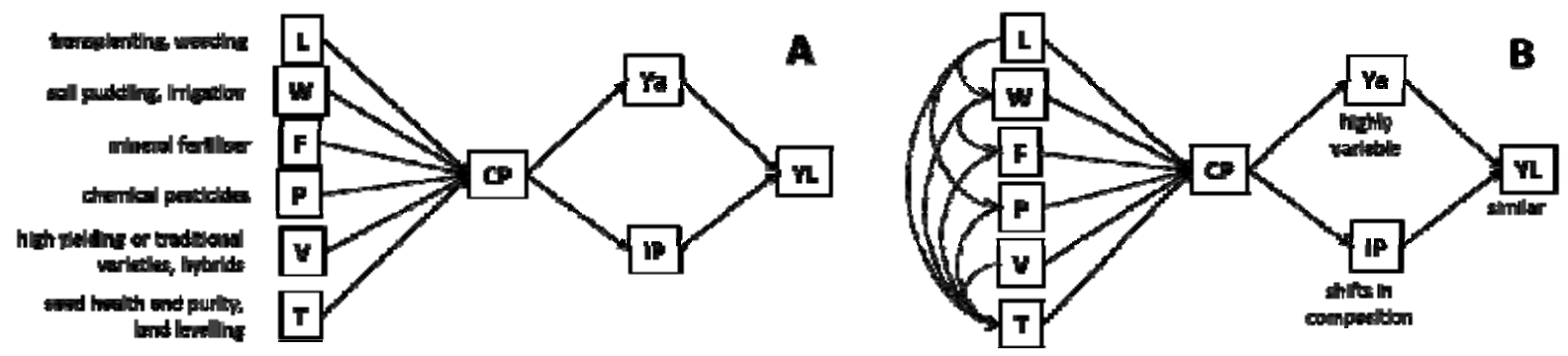

A: summarised components of crop profiles; B: interplay of crop profile components influencing injury profiles, attainable yields, and yield losses.

CP: crop profile; IP: injury profile; Ya: attainable yield; YL: yield loss;

L: labour; W: water; F: fertiliser; P: pesticides; V: varieties and germplasm; T: technology level.

This article is protected by copyright. All rights reserved. 
A

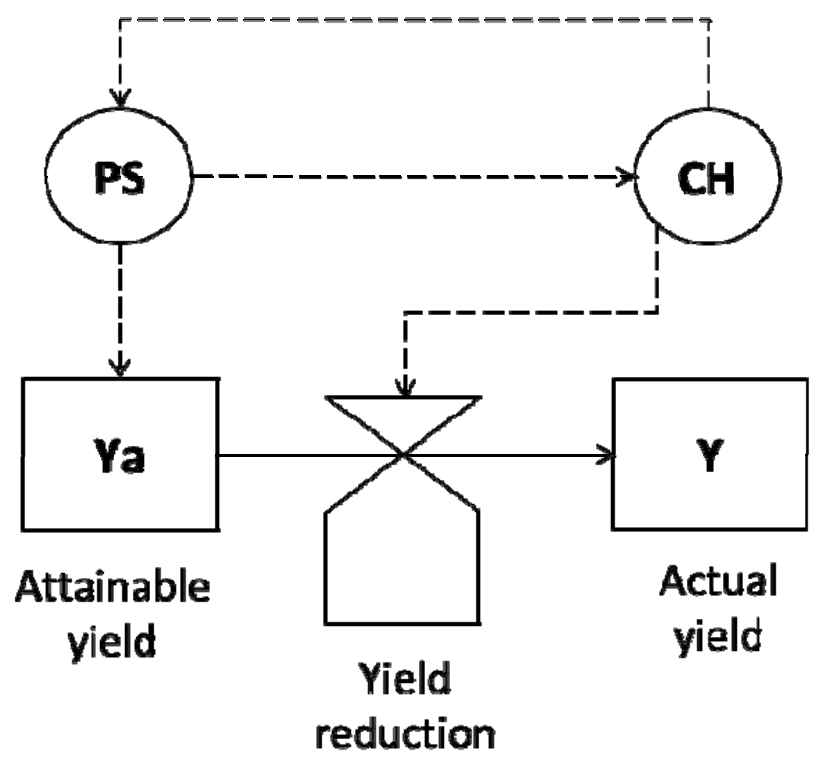

B

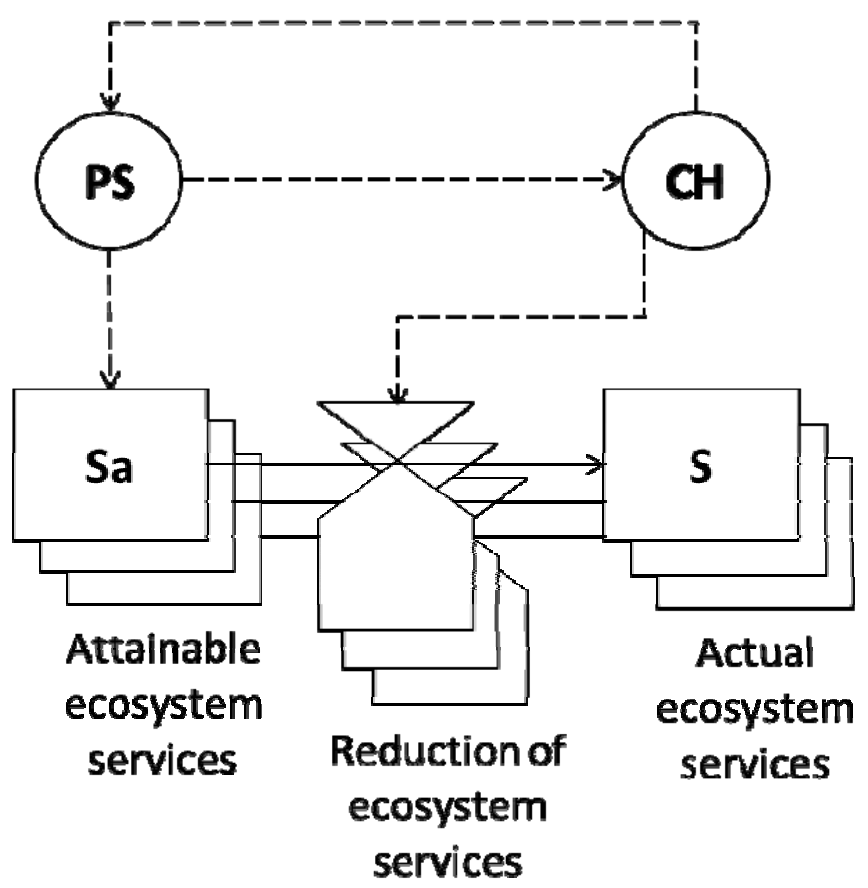

Fig. 5. Relationships between Production Situations, Crop Health, and crop performance.

A. Yield performance.

B. Multidimensional ecosystem services performances.

PS: production situation; $\mathrm{CH}$ : crop health; $\mathrm{Ya}$ : attainable yield; $\mathrm{Y}$ attainable yield; Sa: attainable ecosystem services; S: actual ecosystem services.

This article is protected by copyright. All rights reserved. 